\title{
OPTIMIZATION OF PROCESS PARAMETERS OF CNC AWJM FOR TITANIUM ALLOY GRADE -5
}

\author{
G Prasanna kumar', Y Munirathnam², Dr CH Lakshmi Tulasi ${ }^{3}$ N Rajesh $^{4}$ \\ ${ }^{1}$ M.Tech student, Mechanical Engineering, Chadalawada Ramanamma Engineering College, Andhra Pradesh, India \\ ${ }^{2}$ Assitant Professor, Mechanical Engineering, Chadalawada Ramanamma Engineering College, Andhra \\ Pradesh,india \\ ${ }^{3}$ Associate Professor, Mechanical Engineering, Chadalawada Ramanamma Engineering College, Andhra Pradesh \\ India \\ ${ }^{4}$ Associate Professor, Mechanical Engineering, Chadalawada Ramanamma Engineering College, Andhra Pradesh \\ India
}

\begin{abstract}
Abrasive Water Jet Machining is an effective technology for processing various materials. In AWJM process the work piece material is removed by impact erosion of high velocity jet of water mixed with abrasive particles. For present work three parameters namely traverse speed, standoff distance, abrasive flow rate are considered as input parameters with three levels and Taguchi's L9 Orthogonal Array (OA) was considered for experimentation. In this work Titanium Alloy Grade 5 was considered work piece material and Garnet 80mesh as abrasive particle. The relationship between control parameters and Output parameter (MRR and Ra) is developed by means of linear regression.
\end{abstract}

Key Words: Abrasive Water Jet Machining (AWJM), Taguchi Method, Orthogonal Array (OA), Process Parameters, Titanium Grade 5, MRR and Ra.

\section{INTRODUCTION}

AWJM is a well-established non-traditional machining process. Abrasive water jet machining (AWJM) is a process of material removal from a work piece by the application of high speed stream of abrasive particles carried with water from a nozzle.

Abrasive water jet machining (AWJM) is a mechanical material removal process used to erode holes and cavities by the impact of abrasive particles of the slurry on hard and brittle materials. In Abrasive Water Jet Machining, the abrasive particles are mixed with water and forced through the small nozzle at high pressure so that the abrasive slurry impinges on the work surface at high velocity. Each of the two components of the jet, i.e., the water and the abrasive materials have both separate purpose and a supportive purpose.

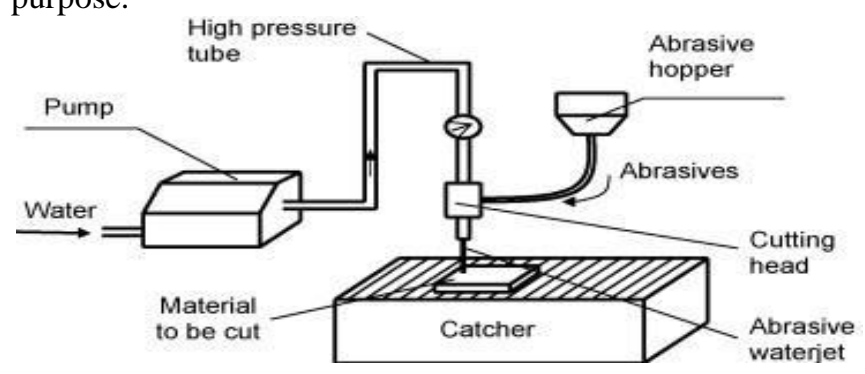

Fig -1: The basic Principle of AWJM
The primary purpose of the abrasive material in the jet stream is to provide the erosive forces. The water in the jet acts as the coolant and carries both the abrasive material and eroded material to clear of the work.

\section{LITERATURE REVIEW}

Punit Grover et.al [1] presented study of Aluminium oxide Abrasive on Tempered Glass in Abrasive Jet Machining Using Taguchi Method, in which they used Pressure, Angle between the work piece and nozzle jet \& Abrasive mesh size as input parameters. After the Experiment they conclude that the larger is better result for calculating MRR value also they analyzed AJM process using the conceptual signal to noise ratio approach, regression analysis and analysis of variance. R.VADGAMA et.al [2] have described in their paper about effect of material removal rate during machining on glass of $3 \mathrm{~mm}, 4 \mathrm{~mm}, 6 \mathrm{~mm}$ by Abrasive Jet Machine (AJM). Input parameters are stand-off distance and pressure. The material removal rate was considered the quality characteristics with the concept of "larger-thebetter". The responses measured are MRR. They have used Taguchi technique for the optimization of process parameters. Mr.Sachin Kumar et.al [3] has been studied that MRR of soda lime glass at different parameters on Abrasive Jet Machining. Input parameters are pressure, angle, abrasive size, nozzle tip distance and L9 Orthogonal Array is used for finding of Metal Removal Rate (MRR). Pradeep Kumar Sharma, et.al [4] have described in this paper that the effects of parameters of AJM machining on material 
removal rate (MRR, gm/min) overcut $(\mathrm{mm})$ and taper cut $(\mathrm{mm})$ during machining of glass fibre reinforced plastic. An AJM setup has been fabricated for this purpose. Tungsten carbide nozzle having diameter $1.2 \mathrm{~mm}, 1.5 \mathrm{~mm}, 2.3 \mathrm{~mm}$ is used and Taguchi's L9 Orthogonal Array is used for experimentation. Tarun Batra, et.al [5] have described in his paper that the effects of various input parameters in abrasive Jet machining (AJM) on the output parameter(Metal Removal Rate [MRR]).This paper presents an extensive review of the current state of research and development in the abrasive jet machining process. Further difficulties and future development in abrasive jet machining are also projected. This review paper will help researchers, students, manufactures to understand policy makers widely.

\section{DESIGN OF EXPERIMENTS}

\subsection{Selection of Materials}

The work piece material used in this study is Titanium alloy Grade 5 and its chemical composition is given in table 1 and parameters in table 2 .

Table - 1: Chemical composition of Titanium alloy (Grade 5)

\begin{tabular}{|c|l|c|}
\hline S.No & \multicolumn{1}{|c|}{ Properties } & \% of composition \\
\hline 1. & Hydrogen(H) & 0.015 \\
\hline 2. & Carbon(C) & 0.08 \\
\hline 3. & Ferrous(Fe) & 0.03 \\
\hline 4. & Nitrogen(N) & 0.05 \\
\hline 5. & Aluminium(Al) & $5.5-6.75$ \\
\hline 6. & Oxygen(O) & 0.20 \\
\hline 7. & Vanadium(V) & $3.5-4.5$ \\
\hline 8. & Others & 0.40 \\
\hline 9. & Titanium(Ti) & Bal \\
\hline
\end{tabular}

Table - 2 : Parameters of AWJM

\begin{tabular}{|c|c|}
\hline Control Factors & Symbols \\
\hline Traverse speed & A \\
\hline Abrasive flow rate & B \\
\hline Standoff distance & C \\
\hline
\end{tabular}

\subsection{Experimental Work}

The experiments were performed on S-3015 AWJM CNC machine, manufactured by Water Jet Germany Private Limited. Water jet cutting uses high pressure water to cut softer material like rubber and abrasive jets adds abrasive to water to cut harder material like steel, glass and titanium. The high pressure water is forced through a tiny orifice to concentrate high energy in a tiny area to cut.

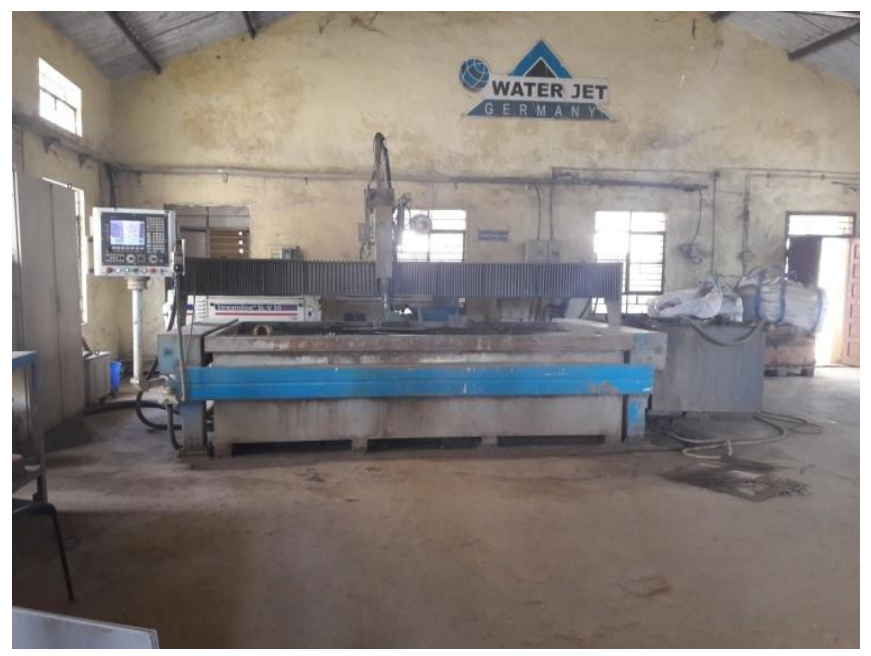

Fig -2: CNC Controlled Abrasive Water Jet Machine

Table No-3 : Machine specifications

\begin{tabular}{|l|l|}
\hline Model No. & S-3015 \\
\hline Jet Pressure & $4000 \mathrm{bar}$ \\
\hline Max. Traverse Speed & $4000 \mathrm{~mm} / \mathrm{min}$ \\
\hline $\begin{array}{l}\text { Max. Stand-off } \\
\text { Distance }\end{array}$ & $4 \mathrm{~mm}$ \\
\hline Movement in X-axis & $3 \mathrm{~m}$ \\
\hline Movement in Y-axis & $1.5 \mathrm{~m}$ \\
\hline Impact Angle & 90 deg \\
\hline Materials to be cut & Ant type of material \\
\hline
\end{tabular}




\section{RESULTS AND ANALYSIS}

The results obtained are analyzed using $\mathrm{S} / \mathrm{N}$ ratios, Response table and Response graphs with the help of Mini

Tab software. Mini Tab is a computer program designed to perform basic and advanced statistical functions. It is a popular statistical analysis package for scientific applications, in particular for design and analysis of experiments. In this experimental results are analyzed and Regression equation is developed to predict the metal removal rate and graphs.

Table - 4 : Material Removal Rate (MRR) and Surface Roughness (Ra)

\begin{tabular}{|c|c|c|c|c|c|}
\hline $\begin{array}{c}\text { Traverse } \\
\text { Speed } \\
(\mathrm{mm} / \\
\mathrm{sec})\end{array}$ & $\begin{array}{c}\text { Abrasive } \\
\text { Flow } \\
\text { Rate } \\
(\mathrm{mm} / \mathrm{sec})\end{array}$ & $\begin{array}{c}\text { Stand } \\
\text {-off } \\
\text { Dista } \\
\text { nce } \\
(\mathrm{mm})\end{array}$ & $\begin{array}{c}\text { Machining } \\
\text { Time } \\
(\mathrm{sec})\end{array}$ & $\begin{array}{c}\text { MRR } \\
\left(\mathrm{mm}^{3} / \mathrm{sec}\right)\end{array}$ & $\begin{array}{c}\text { Ra } \\
(\mu \mathrm{m})\end{array}$ \\
\hline 60 & 100 & 1 & 54.21 & 7.440 & 8.14 \\
\hline 60 & 150 & 2 & 49.10 & 8.960 & 8.63 \\
\hline 60 & 200 & 3 & 49.63 & 8.755 & 8.34 \\
\hline 70 & 100 & 2 & 42.02 & 10.385 & 8.44 \\
\hline 70 & 150 & 3 & 42.33 & 10.226 & 6.99 \\
\hline 70 & 200 & 1 & 42.30 & 9.924 & 7.85 \\
\hline 80 & 100 & 3 & 37.28 & 11.240 & 10.67 \\
\hline 80 & 150 & 1 & 36.40 & 10.409 & 6.13 \\
\hline 80 & 200 & 2 & 35.93 & 11.889 & 7.87 \\
\hline & & & & & \\
\hline
\end{tabular}

\subsection{Analysis Of Experimental Data Using Taguchi} Technique

4.1.1 Taguchi Analysis: MRR versus TS, AFR, SD
Table - 5 : Response table for Means (MRR)

\begin{tabular}{|c|c|c|c|}
\hline $\begin{array}{c}\text { Leve } \\
1\end{array}$ & $\begin{array}{c}\text { Travers } \\
\text { e Speed }\end{array}$ & $\begin{array}{c}\text { Abrasive } \\
\text { Flow Rate }\end{array}$ & $\begin{array}{c}\text { Stand-off } \\
\text { Distance }\end{array}$ \\
\hline 1 & 8.385 & 9.688 & 9.258 \\
\hline 2 & 10.178 & 9.865 & 10.411 \\
\hline 3 & 11.179 & 10.189 & 10.074 \\
\hline Delta & 2.794 & 0.501 & 1.154 \\
\hline Rank & 1 & 3 & 2 \\
\hline
\end{tabular}

Table - 6 : Response table for S/N Ratios (MRR) (Larger is Better)

\begin{tabular}{|c|c|c|c|}
\hline Level & $\begin{array}{c}\text { Traverse } \\
\text { Speed }\end{array}$ & $\begin{array}{c}\text { Abrasive } \\
\text { Flow Rate }\end{array}$ & $\begin{array}{c}\text { Stand-off } \\
\text { Distance }\end{array}$ \\
\hline 1 & 18.44 & 19.59 & 19.24 \\
\hline 2 & 20.15 & 19.86 & 20.29 \\
\hline 3 & 20.96 & 20.09 & 20.02 \\
\hline Delta & 2.51 & 0.50 & 1.05 \\
\hline Rank & 1 & 3 & 2 \\
\hline
\end{tabular}

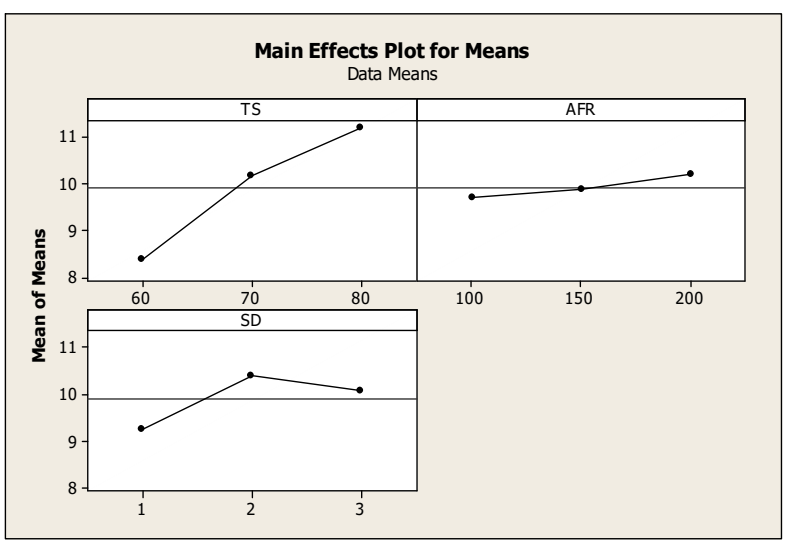

Fig - 3 : Response Graphs for Means (MRR) 


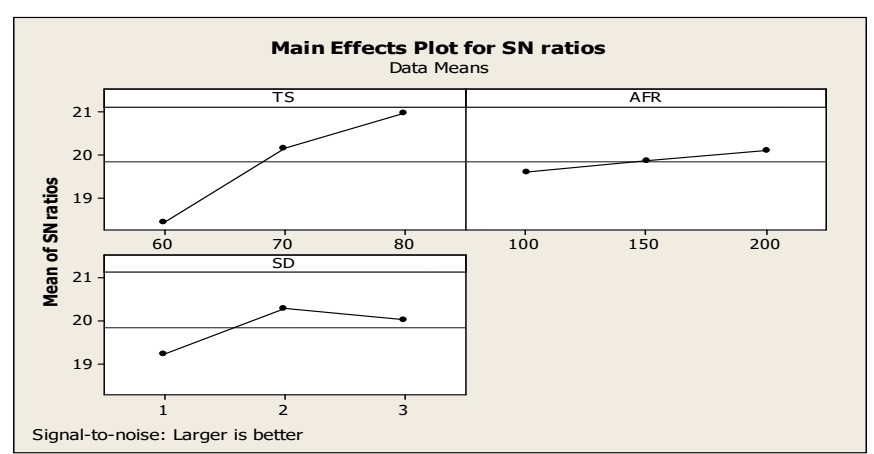

Fig - 4 : Response Graphs for S/N ratio (MRR)

Table - 7 : Optimum level combination for MRR

\begin{tabular}{|c|c|}
\hline Control Factors & Optimum Level \\
\hline TS & 80 \\
\hline SD & 2 \\
\hline AFR & 200 \\
\hline
\end{tabular}

\subsubsection{Taguchi Analysis: Ra versus TS, AFR, SD}

Table $-\mathbf{8}$ : Response table for Means (Ra)

\begin{tabular}{|c|c|c|c|}
\hline Level & $\begin{array}{c}\text { Traverse } \\
\text { Speed }\end{array}$ & $\begin{array}{c}\text { Abrasive } \\
\text { Flow Rate }\end{array}$ & $\begin{array}{c}\text { Stand-off } \\
\text { Distance }\end{array}$ \\
\hline 1 & 8.370 & 9.083 & 7.373 \\
\hline 2 & 7.760 & 7.250 & 8.313 \\
\hline 3 & 8.223 & 8.020 & 8.667 \\
\hline Delta & 0.610 & 1.833 & 1.293 \\
\hline Rank & 3 & 1 & 2 \\
\hline
\end{tabular}

Table - 9 : Response table for S/N Ratios (Ra) (Smaller is

\begin{tabular}{|c|c|c|c|}
\hline Level & $\begin{array}{c}\text { Traverse } \\
\text { Speed }\end{array}$ & $\begin{array}{c}\text { Abrasive } \\
\text { Flow Rate }\end{array}$ & $\begin{array}{c}\text { Stand-off } \\
\text { Distance }\end{array}$ \\
\hline 1 & -18.45 & -19.10 & -17.29 \\
\hline 2 & -17.77 & -17.12 & -18.39 \\
\hline 3 & -18.08 & -18.08 & -18.63 \\
\hline Delta & 0.68 & 1.98 & 1.34 \\
\hline Rank & 3 & 1 & 2 \\
\hline
\end{tabular}

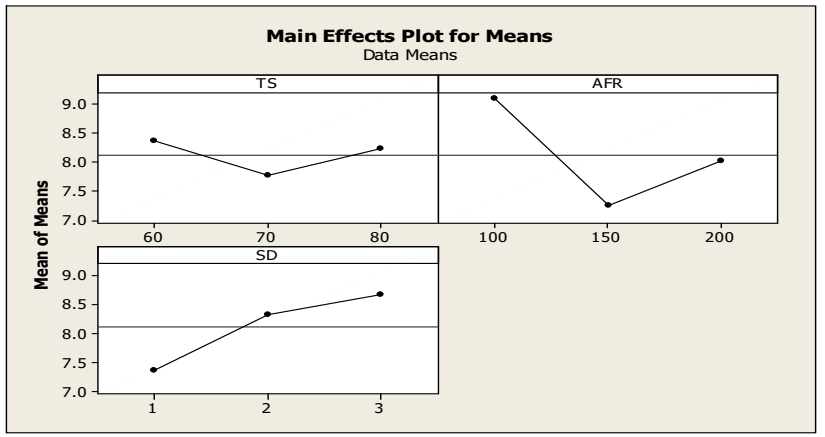

Fig - 5 : Response Graphs for Means (Ra)

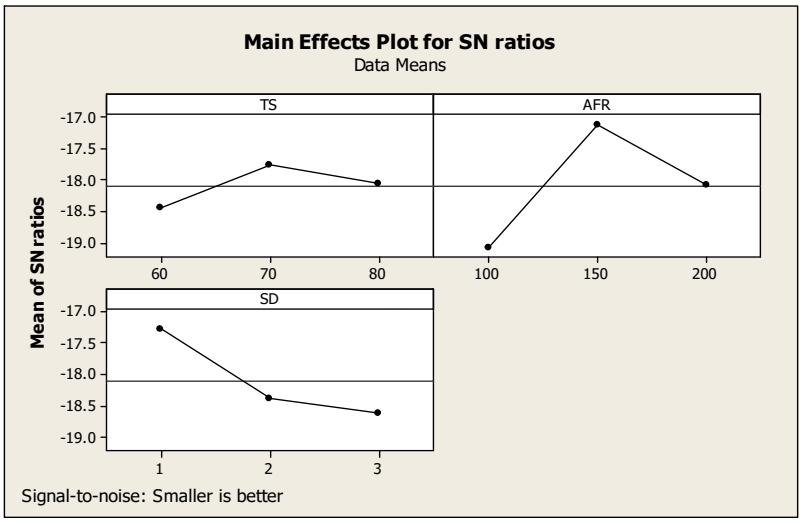

Fig - 6 : Response Graphs for S/N ratio (Ra)

Table - 10 : Optimum level combination for Ra

\begin{tabular}{|c|c|}
\hline Control Factors & Optimum Level \\
\hline TS & 70 \\
\hline AFR & 150 \\
\hline SD & 1 \\
\hline
\end{tabular}

\subsection{Development Of Regression Equation}

The objective of multiple regression analysis is to construct a model that explains as much as possible, the variability in a dependent variable, using several independent variables.

- $\quad$ Regression equation for MRR

$\mathrm{MRR}=-1.43+0.140 \mathrm{TS}+0.00501 \mathrm{AFR}+0.408 \mathrm{SD}$

- $\quad$ Regression for Ra

$\mathrm{Ra}=8.93-0.0073 \mathrm{TS}-0.0106 \mathrm{AFR}+0.647 \mathrm{SD}$ 
Table - 11: Experimental and Predicted values for MRR

\begin{tabular}{|c|c|c|}
\hline S.No & EXPERIMENTAL & PREDICTED \\
\hline 1 & 7.44 & 7.879 \\
\hline 2 & 8.96 & 8.5375 \\
\hline 3 & 8.755 & 9.196 \\
\hline 4 & 10.385 & 9.687 \\
\hline 5 & 10.226 & 10.3455 \\
\hline 6 & 9.924 & 9.78 \\
\hline 7 & 11.24 & 11.495 \\
\hline 8 & 10.409 & 10.9295 \\
\hline 9 & 11.889 & 11.588 \\
\hline
\end{tabular}

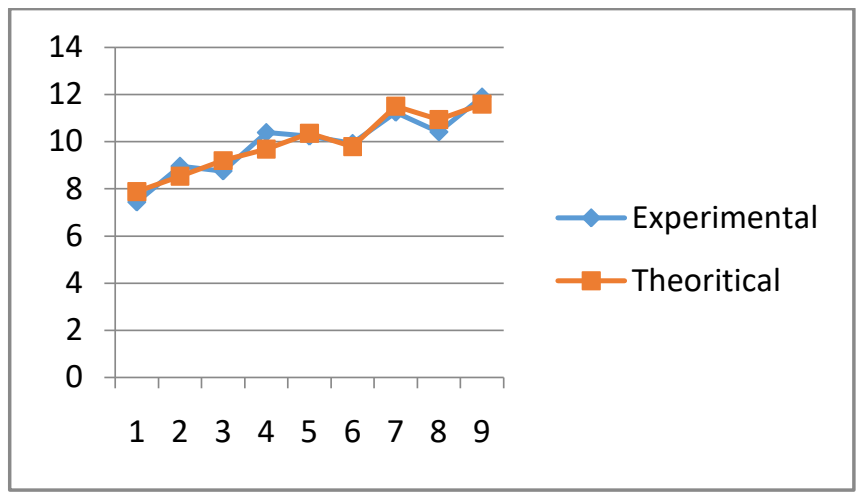

Fig - 7 : Comparison graph for MRR

\subsection{Comparison Graph For Experimental And} Predicted Values Of Ra

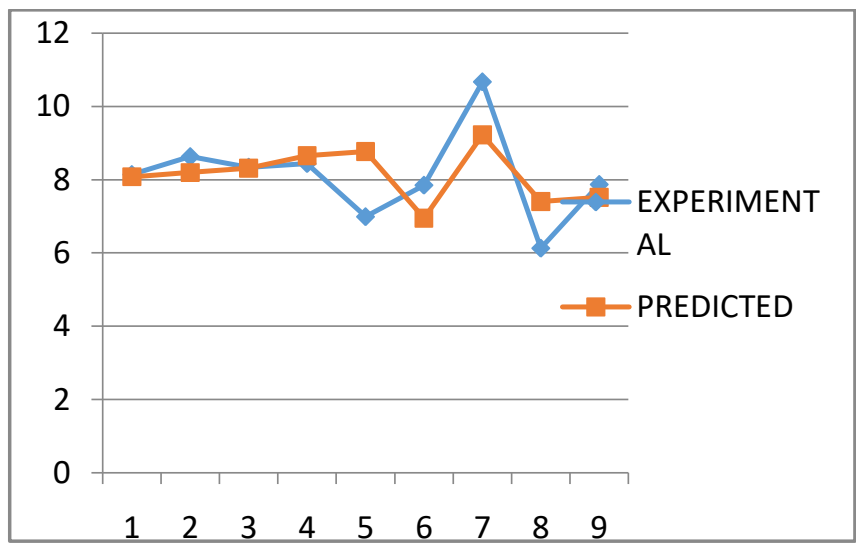

Fig - 8 : Comparison graphs for $\mathrm{Ra}$

\section{CONCLUSION}

Based on the results and discussion the following conclusions are drawn.

- It is observed that the effect of Traverse Speed is maximum on MRR followed by Standoff distance, and Abrasive flow Rate.

- The optimal parameter setting for maximum MRR is obtained at Traverse Speed $8 \mathrm{~mm} / \mathrm{s}$, Standoff distance $2 \mathrm{~mm}$, Abrasive flow Rate $200 \mathrm{~mm} / \mathrm{s}$.

- It is observed that the effect of Abrasive flow rate is maximum on $\mathrm{Ra}$ followed by Standoff distance, and Traverse Speed.

- The optimal parameter setting for good surface finish is obtained at Abrasive flow rate $150 \mathrm{~mm} / \mathrm{s}$, Standoff distance $1 \mathrm{~mm}$, and Traverse Speed $70 \mathrm{~mm} / \mathrm{sec}$.

- The developed regression equation is used to predict the MRR with $6.77 \%$ error.

- The developed regression equation is used to predict the Ra with $4.26 \%$ error. 


\section{REFERENCES}

[1]. Punit Grover, "Study of Aluminium oxide Abrasive on Tempered Glass in Abrasive Jet Machining Using Taguchi Method" International Journal of Advance Research and Innovation, Volume 2, Issue 1 (2014) 237-241, ISSN 23473258 .

[2]. R.VADGAM, "Experimental Analysis of Glass on Abrasive Jet Machine (AJM) using Taguchi Method", International Journal of innovative science Engineering \& Technology, Vol. 2 issue 4, April 2015.

[3]. Sachin Kumar, "A Research Paper on Study the MRR of Soda Lime Glass at different parameters of Abrasive Jet Machine", International Journal of Enhanced Research in Science Technology \& Engineering, Vol.3, Issue 6, June 2014, PP (307-318) .

[4]. Pradeep Kumar Sharma, "A Comparative Analysis of Process Parameters during Machining of Glass Fibre Reinforced Plastic by AJM", International Journal of Advance Foundation and Research in Science \& Engineering (IJAFRSE) Volume 1, Issue 3, August 2014.

[5]. Tarun Batra, "The effects of various input parameters in Abrasive Jet machining (AJM) on the output parameter(Metal Removal Rate (MRR))", International Journal of Research in Aeronautical and Mechanical Engineering,vol.3 issue 12, December 2015.

[6]. M Chithirai Pon Selvan, N.Mohana Sundara Raju "Assessment of Process Parameters in Abrasive Water Jet Cutting of Stainless Steel", International Journal of Advances in Engineering \& Technology, ,ISSN:2231-1963, July 2011.

[7]. B Satyanarayana, G Srikar "Optimization of Abrasive Water Jet Machining Process Parameters using Taguchi Grey Relational analysis(TGRA)",International journal of Mechanical and Production Engineering,ISSN:23202092, Volume-2,Issue-9,September-2014.

[8]. Mayur M.Mhamunkar, Niyati Raut "Process parameter Optimization of CNC Abrasive Water Jet Machine for Titanium $\mathrm{Ti}$ 6A14V,International Journal of Advance Industrial Engineering,Volume-5,No.3,September-2017.

[9]. N.S Pawar, R.R Lakhe, "The Effect of Change in design of Vibrating Chamber for an Experimental Analysis for Sea Sand as an Abrasive Material in an Abrasive Water Jet Machining Process for Mild Steel Nozzle", International Journal of Current Engineering and Technology,E-ISSN 2277-4100,February-2014.

[10].D.V Srikanth, M.Sreenivasa rao, "Machining of FRP Composites by Abrasive Jet Machining Optimization using Taguchi, International Journal of Aerospace, Industrial and Mechatronics Engineering,Volume-8,No.3, 2014.

\section{BIOGRAPHIES}

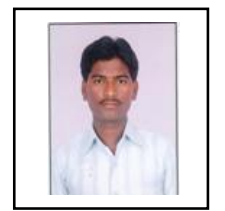

Prasanna kumar received his (MTech) degree in CAD/CAM from Chadalawada Ramanamma Engineering

College,Tirupathi,India.

Munirathnam received his $\mathrm{M}$ Tech degree in CAD/CAM from

Chadalawada Ramanamma Engineering college,Tirupathi,India in 2015.He is having 2 years teaching experience.

Dr. CH. Lakshmi Tulasi working as a Associate Professor in Chadalawada Ramanamma Engineering college,Tirupathi,India.

N Rajesh working as a Associate Professor in Chadalawada Ramanamma Engineering College Tirupati, India. 